\title{
Protective Effects of HEAC and its Primary Active Compound on HCl-ethanol Induced Gastritis in Rats
}

\author{
Won-sik Choi ${ }^{1 *}$, Do-Yoen Jang ${ }^{2}$, Gyung-Rak Lee ${ }^{1}$ and Seung-Han Kim ${ }^{1}$ \\ ${ }^{1}$ Department of Biotechnology, Soonchunhyang University \\ ${ }^{2}$ Division of Synthesis Research Laboratory, Dongbang FTL

\section{흰쥐에서 염산-에탄올로 유발된 위염에 대한 $\mathrm{HEAC}$ 추출물과 그 주성분의 억제효과} \\ 최원식 $1^{*}$, 장도연 $^{2}$, 이경락 ${ }^{1}$, 김승한 $^{1}$ \\ ${ }^{1}$ 순천향대학교 생명공학과, ${ }^{2}$ 동방 $\mathrm{FTL}$ 합성연구소
}

\begin{abstract}
The purpose of this study is to evaluate the gastric mucosal damage effect by Hericium erinaceus cultibated with Artemisia capillaris (HEAC) with $0.15 \mathrm{M} \mathrm{HCl}$ in ethanol in rats. Among them, $80 \%$ ethanol extract showed potent inhibitory effect (67.7\%) on gastritis. Using solvent fractionation, $80 \%$ ethanol extract of HEAC was separated into five fractions with $n$-hexane, methylene chloride, ethyl acetate, $n$-butanol and water. As a result, fractions obtained with methylene chloride exhibited strong inhibitory effects on gastritis. With this result, the methylene chloride extract was analyzed by GC/MS, HPLC, IR and $\operatorname{NMR}\left({ }^{1} \mathrm{H},{ }^{13} \mathrm{C}\right)$ to identify primary active components and the main component in the extract was identified as ethyl linoleate. The effective does $\left(\mathrm{ED}_{50}\right)$ values of $80 \%$ ethanol extract of HEAC and ethyl linoleate showed 22.6 and $6.4 \mathrm{mg} / \mathrm{kg}$, respectively and these values were higher than those of stillen $(44.2 \mathrm{mg} / \mathrm{kg})$ and selbex $(46.5 \mathrm{mg} / \mathrm{kg})$. Therefore, the administration of $80 \%$ ethanol extract of HEAC and ethyl linoleate have a strong protective effect agasint the gastritis induced by $\mathrm{HCl}$-ethanol and may be promising new drug for treating gastritis and gastric ulcer.
\end{abstract}

요 약 노루궁뎅이 버섯 균사체를 인진쑥 배지에 배양시킨 배양물(HEAC)을 여러 농도의 에탄올-물의 용액으로 추출하고, 쥐에서 위염 유발시약 $(0.15 \mathrm{M}$ 염산-에탄올 용액)에 의한 위점막 손상에 대하여 추출물들의 위염 억제효과실험을 실시하였 다. 그 중 $80 \%$ 에탄올 추출물은 위염에 대하여 $67.7 \%$ 로 우수한 억제효과를 나타내었다. 용매별 분획으로 $\mathrm{HEAC}$ 의 $80 \%$ 에탄올 추출물을 노르말 헥산, 염화메틸렌, 초산에틸, 노르말 부탄올과 증류수를 이용하여 5 가지 분획으로 분리하였다. 그 결과, 노르말 헥산과 염화메틸렌 분획들이 위염에 대하여 우수한 억제효과를 나타내었다. 이에 따라 염화메틸렌 추출물 에 대하여 GC/MS, HPLC, IR and NMR $\left({ }^{1} \mathrm{H},{ }^{13} \mathrm{C}\right)$ 을 이용하여 생리활성 주성분의 구조를 확인한 결과 ethyl linoleate임을 확인하였다. 또한, $\mathrm{HEAC}$ 의 $80 \%$ 에탄올 추출물과 ethyl linoleate의 $\mathrm{ED}_{50}$ 값이 각각 22.6 과 $6.4 \mathrm{mg} / \mathrm{kg}$ 을 나타내어 대조약제 인 stillen $(44.2 \mathrm{mg} / \mathrm{kg})$ 과 selbex $(46.5 \mathrm{mg} / \mathrm{kg})$ 보다 우수한 억제효과가 있음을 확인하였다. 그러므로, HEAC의 $80 \%$ 에탄올 추출물과 ethyl linoleate는 염산-에탄올에 의하여 유발된 위염에 대하여 우수한 억제효과를 가지고 있으며, 새로운 위염,위 궤양 치료제로 개발될 수 있을 것으로 기대된다.

Key Words : HEAC, Gastritis, Rat, Ethyl linoleate, $80 \%$ ethanol extract

This work was supported by Soonchunhyang University.

*Corresponding Author: Won Sik Choi

Tel: +82-41-530-1351 email: wschoi@sch.ac.kr

Received January 26, 2012

Revised (1st March 21, 2012, 2ed March 28, 2012)

Accepted April 29, 2012 


\section{Introduction}

The generation of reactive oxygen species (ROS) caused by alcohol consumption has been referred to acute gastric lesions. Other factors such as stress, Helicobacter pylori infection, and administration of non-steroidal anti-inflammatory drugs also evoke gastritis and gastric ulcers, leading to gastric cancers. Gastric cancer has been recognized as the first leading cause of cancer death in Korea and attention to epidemiologic associations between risk factors and gastric cancer. Risk factors with old age, male gender, H. pylori seropositivity and smoking have been determined in Korean population for metaplastic gastritis, precancerous lesion of gastric cancer[1].

In relation to risk factors in Korean gastritis, the prevalence of $H$. pylori infection dramatically increases and reaches up to $50 \%$ at 5 years of age, and $90 \%$ in asymptomatic adults over the age of 20[2].

In the last decades in Korea, many efforts have contributed to discover new gastroprotective drugs from natural products and some plants such as araloside A from Aralia elata and DA-9601 obtained from Artemisia asiatica are good natural sources to treat gastric ulcers [3-4], and eupatilin is an ethanol extract of Artemisia capillaris which has been used as a traditional oriental medicine with the anti-complementary activity[5].

Recently, HEAC have showed inhibitory effects on the biotransformation of aflatoxin $B_{1}$ to aflatoxin $B_{1}$ 8,9-epoxide which forms a single initial DNA added with the guanyl $\mathrm{N}_{7}$ atom in the DNA sequence[6], and interferon-inducing activity[6]. In addition, HEAC have possessed the inhibitory effect on the proliferation of human VSMCs and the protective effects on $\mathrm{CCl}_{4}$-induced acute hepatic damage in rats[7].

In this study, HEAC was evaluated for gastroprotective effect in the $\mathrm{HCl}$ ethanol-induced gastric lesions in rats. By a serial bioassay-guided separation, a potential gastroprotective compound from HEAC was isolated and identified as ethyl linoleate.

\section{Materials and methods}

\section{1 materials}

\subsubsection{Chemicals}

EtOH and diethyl ether (ACS grade) were purchased from Duksan (Suwon, Korea). The chemical reagents used in this study were from Sigma Chemical Co. (St. Louis, MO, USA). HEAC was supplied by Cosis Bio Company. Stillen was obtained from Dong-A Pharmaceutical. Selbex was supplied by Han-Il Pharm Company.

\subsubsection{Biological materials}

Male SPF Sprague-Dawley rats (180-210 g) were used in the experiments. All animals were housed in a temperature-controlled room with a $12 \mathrm{~h}$ light period. They were fed commercial solid food (Samyang Yuji Co. Ltd., Seoul) and tap water ad libitum. The test materials were suspended in $0.2 \%$ carboxymethylcellulose solution and given in a volume of $0.2 \mathrm{~mL} / 100 \mathrm{~g}$ body weight. The doses of the test materials were chosen based on the yields obtained from the original extract or fractions. The room temperature was maintained at $25^{\circ} \mathrm{C}$.

\section{2 methods}

\subsubsection{Isolation and Identification}

HEAC $(3.0 \mathrm{~kg})$ was extracted two times with $80 \%$ ethanol $(25 \mathrm{~L})$ at room temperature for 2 days and the extract was filtered. The resultant extract was combined and concentrated under reduced pressure at $40{ }^{\circ} \mathrm{C}$ to yield about $11.0 \%$ (based on the weight of the dried HEAC). The $80 \%$ ethanol extract of HEAC $(30.0 \mathrm{~g})$ was sequentially partitioned into $n$-hexane $(3.9 \mathrm{~g})$, methylene chloride (8.2 g), ethyl acetete (2.9 g), butanol (2.3 g), and water $(12.7 \mathrm{~g})$ fractions for bioassay. The organic solvent fractions were concentrated to dryness by rotary evaporation at $40^{\circ} \mathrm{C}$, while the water fraction was freeze-dried.

The methylene chloride fraction $(10.0 \mathrm{~g})$ was chromatographed on a silica gel column (70-230 mesh, 500.0 g, 5.5 x 70 cm; Merck, Darmstadt, Germany), and successively eluted with a stepwise gradient of dichloromethane/methanol (100/0, 90/10, 80/20, 70/30, $60 / 40,50 / 50$, and $0 / 100 \mathrm{v} / \mathrm{v})$.

Column fractions were analyzed by thin-layer chromatography (TLC; Silica gel G), and fractions with a similar TLC pattern were pooled. The bioactive fraction $(1.5 \mathrm{~g})$ was successively rechromatographed on a silica gel column, using a stepwise gradient of $n$-hexane/ethyl 
acetate $(90 / 10,80 / 20,70 / 30,60 / 40$, and $0 / 100 \mathrm{v} / \mathrm{v})$. For further separation of the constituents, the active $60 / 40$ fraction $(0.5 \mathrm{~g})$ was fractionated by preparative highperformance liquid chromatography (HPLC;Spectra System P2000, Thermo Separation Products, San Jose, CA).

The column was a $250 \times 4.6 \mathrm{~mm}$ Cosmosil $5 \mathrm{C}_{18}$-MSП (Nacalai Tesque, Kyoto, Japan). The mobile phase was acetonitrile-water $(25: 75, \mathrm{v} / \mathrm{v})$. The flow rate was 1.0 $\mathrm{mL} / \mathrm{min}$, the effluent was monitored at $254 \mathrm{~nm}$ and the column temperature was set at $30^{\circ} \mathrm{C}$. Finally, active principle $(1.7 \mathrm{mg})$ was isolated at the retention times of $11 \mathrm{~min}$. Structural determination of the active isolates was made by spectroscopic analyses. ${ }^{1} \mathrm{H}-\mathrm{NMR}$ and ${ }^{13} \mathrm{C}-\mathrm{NMR}$ $\begin{array}{llllll}\text { spectra were recorded with a JNM-LA } 400 & \text { F7 }\end{array}$ spectrometer (JEOL, Tokyo, Japan) and chemical shifts were given in $\delta(\mathrm{ppm})$. Fourier transform-infrared (FT-IR) spectra were obtained on a VECTOR 22 spectrometer (BRUKER, Frankfurt, Germany). Gas chromatography/mass spectrometry (GC/MS) was performed on a GC/MSQP5050A (Shimaezu, Kyoto, Japan).

The standard vacuum system consists a $150 \mathrm{~L} / \mathrm{sec}$ turbomolecular vacuum pump and a $50 \mathrm{~L} / \mathrm{min}$ baking rotary pump. Samples volumes of $1 \mu \mathrm{l}$ were analyzed with a GC-17A gas chromatograph coupled to a 4000 ion trap mass spectrometer (Shimaezu, Kyoto, Japan). Derivatized samples were vaporized at $250{ }^{\circ} \mathrm{C}$ in standard split mode (1:25) and separated on a $30 \mathrm{~m} \times 0.25 \mathrm{~mm}$ VB-1701 capillary column with $0.25 \mu \mathrm{m}$ coating equipped with an integrated $10 \mathrm{~m}$ guard column (Shimaezu, Kyoto, Japan). The oven temperature was set at $120^{\circ} \mathrm{C}$, held for $5 \mathrm{~min}$, then increased to $290{ }^{\circ} \mathrm{C}$ at $3.5^{\circ} \mathrm{C} / \mathrm{min}$ and held for 5 min. Helium carrier gas (purity $>99.9 \%$ ) flow was adjusted to $1.5 \mathrm{ml} / \mathrm{min}$. The interface and ion source temperature were set to $200^{\circ} \mathrm{C}$ and electron impact ionization $(70 \mathrm{eV})$ was utilized. The averaged scan was full scanning with a range of $50-1000 \mathrm{~m} / \mathrm{z}$. Metabolites were identified by comparison to the NIST 2005 database (version 2.0, Shimadzu Co., Japan).

\subsubsection{Ethanol/ $\mathrm{HCl}$-induced gastric lesion in rats}

The gastroprotective activity of the samples was assessed in the ethanol- $\mathrm{HCl}$ induced lesion model as previously described[8]. Rats were randomly allotted into nine groups of eight rats in each group and fasted for 24 $\mathrm{h}$ with free access to water prior to the experiment. Fifty minutes after oral administration of samples and the currently used medicines, all groups were orally treated with $0.2 \mathrm{~mL}$ of a solution containing $60 \%$ ethanol- $0.15 \mathrm{M}$ $\mathrm{HCl}$ (ethanol - $\mathrm{HCl}$ ) for gastric lesion induction. Animals were sacrificed by ether overdoes and cervical dislocation $1 \mathrm{~h}$ after the administration of ethanol- $\mathrm{HCl}$, and the stomachs were excised and inflated by injection of saline $(1 \mathrm{~mL})$. The ulcerated stomachs were fixed in $5 \%$ formalin for $30 \mathrm{~min}$ and opened along the greater curvature. Gastric damage visible to the naked eye was observed in the gastric mucosa as elongated black-red lines, parallel to the long axis of the stomach similar to the ethanol-HCl-induced lesions in rats. The length ( $\mathrm{mm})$ of each lesion was measured and the lesion index was expressed as the sum of the length of all lesions. The gastritis pictures were obtained at this stage.

\subsubsection{Calculation of effective dose value}

The equivalent dose causing a $50 \%$ increase in raw $\left(\mathrm{ED}_{50}\right)$ was determined of treatment to different concentrations of samples. Increasing doses of sample were then administered at doses of 10, 20, 30, 40, 75 and $150 \mathrm{mg} / \mathrm{Kg}$. $\mathrm{ED}_{50}$ was calculated in each rat by linear interpolation. The data represent the means \pm standard deviations (SDs) of 3 independent experiments.

\subsubsection{Statistical analysis}

The experimental results were expressed as mean \pm S.D. A one-way analysis of variance (ANOVA). When a significant $(p<0.05)$ effect was detected, the mean values were compared using Dunnett's test. The data were considered significant if the probability was less than 0.05 .

\section{Results}

HEAC and its solvent fractions were assayed against gastric mucosal damage induced by $\mathrm{HCl}$-ethanol solution. Significant differences were observed in the protective activity against the tested HEAC and solvent fractions when compared to the controls and the currently used 
medicines for treating gastritis, selbex and stillen. The protective effects of various fractions of HEAC at the concentration of $40 \mathrm{mg} / \mathrm{kg}$ of rats against gastritis are shown in Table 1.

The $n$-hexane and methylene chloride fraction exhibited very strong protective activities against gastritis with the protection rate of 83.6 and $81.6 \%$, respectively. The ethyl acetate fraction also showed strong activity against gastritis with the protection rate of $62.5 \%$, whereas little protection activities were found in the butanol and water fractions. Due to its potent inhibitory activity against gastritis, the hexane fraction was selected for further study.

The methylene chloride fraction was separated into seven subfractions and very strong protective activity was observed with a subfraction C5 at the concentration of 40 $\mathrm{mg} / \mathrm{kg}$. Silica gel open column chromatography and preparative HPLC were used for further separation of the constituents in the $\mathrm{C} 5$ subfraction $(1.0 \mathrm{~g})$.

[Table 1] Gastroprotective activity of various solvent fractions obtained from the ethanol extract of Hericium erinaceum cultivated with Artemisia capillaris (HEAC) using ethanol/HCl-induced gastric lesion in rats

\begin{tabular}{cccc}
\hline Treat & $\begin{array}{c}\text { Dose } \\
(\mathrm{mg} / \mathrm{Kg})\end{array}$ & $\begin{array}{c}\text { Gastric Lesion rate } \\
(\text { Mean } \pm \text { S.E.M., } \%)\end{array}$ & $\begin{array}{c}\text { Inhibitio } \\
\mathrm{n} \text { rate }(\%)\end{array}$ \\
\hline Normal & - & - & - \\
Control & - & $50.3 \pm 2.5$ & - \\
$80 \%$ EtOH & 40 & $10.8 \pm 3.2^{* *}$ & 67.7 \\
$n$-Hexane & 40 & $9.3 \pm 2.7$ & 83.6 \\
$\begin{array}{c}\text { Methylene } \\
\text { chloride }\end{array}$ & 40 & $8.3 \pm 2.3$ & 81.6 \\
Ethyl & 40 & $18.9 \pm 2.4$ & 62.5 \\
acetate & & $21.0 \pm 8.8$ & 58.3 \\
$n$-Butanol & 40 & $41.1 \pm 2.5$ & 18.3 \\
Water & 40 & $23.0 \pm 5.4^{*}$ & 54.2 \\
Stillen & 40 & $23.5 \pm 4.1^{*}$ & 53.2 \\
Selbex & 40 & & \\
\hline
\end{tabular}

$\mathrm{n}=8$ animals in each group.

Values are expressed as mean \pm standard deviation. In the same column, different Asterisk $(*)$ are statistically different at $p<0.05 ;{ }^{*} \mathrm{p}<0.05,{ }^{* *} \mathrm{p}<0.01$, significantly different from the control group.

The gastroprotective activity-guided fractionation with ethanol/HCl-induced gastric lesion in rats led to the isolation of one active principle that was identified as ethyl linoleate by means of spectroscopic analysis and by direct comparison with authentic compounds. This compound was identified on the basis of the following evidence; ethyl linoleate $\left(\mathrm{C}_{20} \mathrm{H}_{36} \mathrm{O}_{2}, \mathrm{MW}, 308.27\right)$;FT-IR: $\mathrm{V}_{\max }$ (Nujol) $3010(-\mathrm{CH}=\mathrm{CH}-), 2967(\mathrm{CH}$ stretching in $\left.\mathrm{CH}_{3}\right), 2928\left(\mathrm{CH}\right.$ stretching in $\left.\mathrm{CH}_{2}\right), 1739(\mathrm{C}=\mathrm{O}$ stretch in ester), $1664(\mathrm{C}=\mathrm{C}), 1466\left(\mathrm{C}-\mathrm{H}\right.$ bending in $\mathrm{CH}_{2}$ and $\left.\mathrm{CH}_{3}\right)$, 1396 (C-H deformation), 1373 (C-H deformation in $\mathrm{CH}_{3}$ ), 1302 (C-O stretching) $\mathrm{cm}^{-1}$; GC (retention time): 39.4 min; EI-MS (rel. int. \%): m/z $309[\mathrm{M}+\mathrm{H}]^{+}(2), 308\left[\mathrm{M}^{+}\right]$ (25), 306 (2), 280 (2), 263 (20), 164 (11), 150 (13), 109 (32), 95 (59), 81 (85), 67 (100), 72 (7), 41 (80), 29 (50), 27 (25) ; ${ }^{1} \mathrm{H}-\mathrm{NMR}\left(500 \mathrm{MHz}, \mathrm{CDCl}_{3}\right): \delta 0.90(\mathrm{t}, 3 \mathrm{H})$, $1.29(\mathrm{t}, 15 \mathrm{H}), 1.31(\mathrm{~m}, 2 \mathrm{H}), 1.64(\mathrm{~m}, 2 \mathrm{H}), 2.18(\mathrm{t}, 4 \mathrm{H})$, $2.32(\mathrm{t}, 2 \mathrm{H}), 2.63(\mathrm{~s}, 2 \mathrm{H}), 4.13$ (quert, 2H), $5.37(\mathrm{~s}, 2 \mathrm{H})$, $5.43(\mathrm{~s}, \quad 2 \mathrm{H}) ;{ }^{13} \mathrm{C}-\mathrm{NMR}\left(125 \mathrm{MHz}, \mathrm{CDCl}_{3}\right): \delta 14.0$ $\left(\mathrm{CH}_{3}-\mathrm{C}-\mathrm{C}-\mathrm{C}-, \quad \mathrm{CH}_{3}-\mathrm{CH}_{2}-\mathrm{O}-\mathrm{C}=\mathrm{O}\right), 22.5 \quad\left(\mathrm{CH}_{3}-\mathrm{CH}_{2}-\mathrm{C}-\mathrm{C}-\right)$, $25.0 \quad\left(-\underline{\mathrm{CH}}_{2}-\mathrm{C}-\mathrm{C}=\mathrm{O}\right), 26.0 \quad(-\mathrm{C}=\mathrm{C}-\underline{\mathrm{C}}-\mathrm{C}=\mathrm{C}-), 27.5 \quad(-\underline{\mathrm{C}}-\mathrm{C}=\mathrm{C}-)$, 28.5-30.0 (- $\left.\mathrm{CH}_{2}\right), 31.5\left(-\mathrm{CH}_{2}-\mathrm{CH}_{2}-\mathrm{CH}_{3}\right), 34.5 \quad\left(-\underline{\mathrm{CH}}_{2}-\mathrm{C}=\mathrm{O}\right)$,

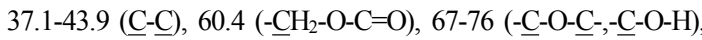

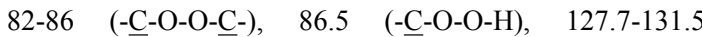
$(-\underline{\mathrm{C}}=\underline{\mathrm{C}}-\mathrm{C}-\underline{\mathrm{C}}=\underline{\mathrm{C}}-), 124.3,131.7-136.0 \quad(-\underline{\mathrm{C}}=\underline{\mathrm{C}}-\underline{\mathrm{C}}=\underline{\mathrm{C}}-\mathbf{}), 142.8$, 145.7, $156.3 \quad(-\underline{\mathrm{C}}=\underline{\mathrm{C}}-\mathrm{C}=\mathrm{O}), 173.7 \quad(-\underline{\mathrm{C}}=\mathrm{O})$.

According to GC/MS, one of the compound of HEAC extract gave a peak for with a retention time of $39.4 \mathrm{~min}$. It was confirmed the ethyl linoeate. However, Artemisia capillaris and Hericium erinaceus extracts did not show a peak of $39.4 \mathrm{~min}$. Therefore, ethyl linoleate compound is thought to be generated during the incuvating.

At $40 \mathrm{mg} / \mathrm{Kg}$, the compound of ethyl linoleate showed its gastroprotective activity with gastric lesion and inhibition rats of $10.8 \pm 3.2$ and $67.7 \%$, while those of stillen and selbex showed $26.5 \pm 5.4,54.2 \%$ and $23.8 \pm 4.1$, $53.2 \%$ against gastritis [Table 2].

As shown in Table 3, compounds ethyl linoleate, stillen and selbex had the $\mathrm{ED}_{50}$ values of $6.4,44.2$ and $46.5 \mathrm{mg} / \mathrm{kg}$, respectively. $\mathrm{ED}_{50}$ value of ethyl linoleate was much stronger than that of the commercial drugs (stillen and selbex).

Figure 1 shows the image of severe gastritis after $\mathrm{HCl}$-ethanol treatment without any drug as control. However, the currently used medicines, stillen and selbex, inhibited gastritis in rats. When compared to these findings, ethyl linoleate had a potent protective effect on the gastritis induced by $\mathrm{HCl}$-ethanol treatment. 
[Table 2] Gastroprotective activity of ethyl linoleate isolated methylene chloride fraction from the ethanol extract of Hericium erinaceum cultivated with Artemisia capillaris (HEAC) using ethanol/HCl-induced gastric lesion in rats.

\begin{tabular}{|c|c|c|c|}
\hline Treat & $\begin{array}{c}\text { Dose } \\
(\mathrm{mg} / \mathrm{Kg})\end{array}$ & $\begin{array}{c}\text { Gastric Lesion rate } \\
(\text { Mean } \pm \text { S.E.M., } \%)^{\text {a) }}\end{array}$ & $\begin{array}{r}\text { Inhibition } \\
\text { rate }(\%)\end{array}$ \\
\hline Normal & - & - & - \\
\hline Control & - & $50.3 \pm 2.5$ & - \\
\hline \multirow[t]{6}{*}{ HEAC } & 150 & $2.7 \pm 1.2$ & 94.6 \\
\hline & 75 & $7.6 \pm 2.4$ & 84.8 \\
\hline & 40 & $16.2 \pm 3.2$ & 67.7 \\
\hline & 30 & $18.2 \pm 4.3$ & 63.8 \\
\hline & 20 & $29.0 \pm 3.5$ & 42.4 \\
\hline & 10 & $32.0 \pm 6.7$ & 36.3 \\
\hline Ethyl & 150 & $0.5 \pm 1.1$ & 99.1 \\
\hline \multirow[t]{6}{*}{ linoleate } & 75 & $7.8 \pm 2.8$ & 84.4 \\
\hline & 40 & $10.8 \pm 3.2$ & 78.5 \\
\hline & 30 & $12.5 \pm 4.6$ & 75.1 \\
\hline & 20 & $17.0 \pm 3.5$ & 66.2 \\
\hline & 10 & $21.4 \pm 3.2$ & 57.5 \\
\hline & 5 & $23.8 \pm 2.8$ & 48.5 \\
\hline \multirow[t]{6}{*}{ Stillen } & 150 & $14.7 \pm 2.8$ & 70.8 \\
\hline & 75 & $20.0 \pm 3.2$ & 60.2 \\
\hline & 40 & $23.5 \pm 5.4$ & 54.2 \\
\hline & 30 & $28.5 \pm 3.6$ & 43.4 \\
\hline & 20 & $29.0 \pm 4.7$ & 42.3 \\
\hline & 10 & $33.5 \pm 7.5$ & 33.4 \\
\hline \multirow[t]{6}{*}{ Selbex } & 150 & $14.5 \pm 5.4$ & 71.1 \\
\hline & 75 & $21.0 \pm 4.6$ & 58.3 \\
\hline & 40 & $23.8 \pm 4.1$ & 53.2 \\
\hline & 30 & $29.4 \pm 5.2$ & 41.5 \\
\hline & 20 & $30.2 \pm 4.8$ & 39.9 \\
\hline & 10 & $37.0 \pm 6.2$ & 26.4 \\
\hline
\end{tabular}

a) $p<0.05$

Values are means \pm SD of three replicated tests. Numbers of animal used in this wtudy was 8 .

[Table 3] Effective dose $\left(\mathrm{ED}_{50}\right)$ value of ethy llinoleate isolated methylene chloride fraction from the ethanol extracts of Hericium erinaceum cultivated with Artemisia capillaris (HEAC) using ethanol/HCl-induced gastric lesion in rats.

\begin{tabular}{cc}
\hline Drugs & $\mathrm{ED}_{50}(\mathrm{mg} / \mathrm{Kg})^{\mathrm{a})}$ \\
\hline HEAC & $22.6 \pm 0.03$ \\
Ethyl linoleate & $6.4 \pm 0.02$ \\
Stillen & $44.2 \pm 0.01$ \\
Selbex & $46.5 \pm 0.01$ \\
\hline
\end{tabular}

a) $p<0.05$

Values are means \pm SD of three replicated tests.

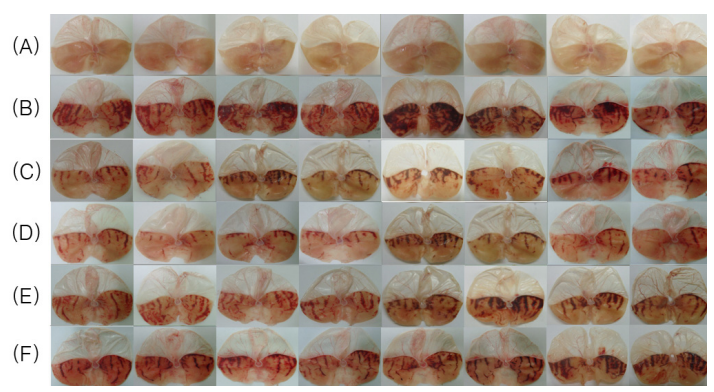

[Fig. 1] Inhibitory effect of gastritis for ethyl linoleate in rats. (A) Normal, (B) Control, (C) HEAC(40mg/kg), (D) Ethyl linoleate $(40 \mathrm{mg} / \mathrm{kg})$, (E) Stillen $(40 \mathrm{mg} / \mathrm{kg}$ ), (F) Selbex $(40 \mathrm{mg} / \mathrm{kg})$.

\section{Discussion}

Hericium erinaceus is a well-known traditional edible mushroom in Korea. The mushroom induces maturation of dendritic cells [9] and its soluble components enhance NK cell activation via production of interleukin-12 in mice splenocytes[10]. Recently, H. erinaceus polysaccharides have been found to induce activities of antioxidant enzymes and anti-skin aging activities[11]. On the other hand, valuable constituents such as hericenone, erinacol, erinacine, and some terpenoids have been isolated from the mushroom and their biological activities such as the stimulatory activities on nerve growth factor have been found[12-13].

Similarly, Artemisia capillaris possesses liver protective effects on $\mathrm{CCl}_{4}$-induced liver fibrosis in rats[14] and liver malondialdehyde levels have been significantly lowered in rats treated with the ethanol-soluble part of a hot-water extract of $A$. capillaris[4]. The inhibitory effects of $A$. capillaris on VSMC proliferation and intimal hyperplasia in the rat have been determined and esculetin in the plant has been isolated and refers to the activity. The mode of inhibitory activity of esculetin blocks cell proliferation via the inhibition of an upstream effector of Ras and downstream events including p42/44 MAPK activation, PI 3-kinase activation, immediates early gene expression as well as NF-kappaB and AP-1 activation[15].

HEAC extracts have showed similar liver protective activity against $\mathrm{CCl}_{4}$-induced acute hepatic damage when compared to the extract of $A$. capillaris. Interestingly, this liver protective activity was not found in the methanol 
extract of $H$. erinaceus grown in media without $A$. capillaris. Therefore, cultivation of the mushroom with $A$. capillaris is important to give the activity to the mushroom. In regard to the biological activity, HEAC shows a potent inhibitory activity on the proliferation of human VSMCs, while H. erinaceus grown in media in the absence of $A$. capillaris shows no inhibitory effects. The inhibitory effects may be caused by new metabolites or constituents derived from A. capillaris[7].

In our fingdings, ethyl linoleate showed a strong inhibitory effect on $\mathrm{HCl}$-ethanol induced gastric mucosal damage in rats. The $\mathrm{ED}_{50}$ value $(6.4 \mathrm{mM})$ of the inhibitory effect was stronger than those of stillen and selbex $\left(\mathrm{ED}_{50}\right.$ value, 44.2 and $\left.46.5 \mathrm{mM}\right)$, the currently used medicine for treating gastritis [Table 3]. The extract was used for further isolation studies and an ethyl linoleate was purified from the active fraction. It was characterized by GC/MS, ${ }^{1} \mathrm{H}-\mathrm{NMR}$ and ${ }^{13} \mathrm{C}-\mathrm{NMR}$. The $\mathrm{ED}_{50}$ value of ethyl linoleate on gastritis was only 6.4 $\mathrm{mg} / \mathrm{kg}$ and it was seven times lower than those of $\mathrm{ED}_{50}$ values of stillen and selbex [Table 3]. Ethyl linoleate is one of the major linoleic acid and feeding polyunsaturated essential fatty acids (linoleic and arachidonic acids) to experimental animals leads to massive increases in prostaglandin concentrations in gastric juice[16,17], and these prevent experimental mucosal injury. Prostaglandins and prostaglandin analogues also profoundly affect human gastric function.

Pharmacologically does they suppress acid secretion[18], stimulate secretion of mucus and bicarbonate[19,20] and protect the gastric mucosa against the harmful effects of salicylates[21], bile acid[22] and ethanol[23]. Their effects on gastrin release are controversial; they have been variously reported to decrease[24] or have no effect on[25] serum gastrin concentration.

Increased intake of polyunsaturated fatty acids could therefore lead to lowered acid secretion and increased gastric mucosal protection[26]. Additionally, a dramatic reduction on gastric lesions induced by $\mathrm{HCl}$-ethanol treatment in rats has been found and the pictures [Fig. 1] clearly showed a dose-dependent effect on the gastritis.

HEAC and ethyl linoleate showed their strong synergically inhibitory effect on gastritis induced by $\mathrm{HCl}$-ethanol and they are potent candidates for medicines to treat gastritis. Further studies are needed to understand structure-activity relationships of coumarins on the remedy of gastritis.

\section{References}

[1] S. Choi, Y. J. Lim and S. K. Park, "Risk factor analysis for metaplastic gastritis in Koreans", World J. Gastroenterol., 12, pp. 2584 - 2587, 2006.

[2] H. S. Youn, G. H. Ko, M. H. Chung, W. K. Lee, M. J. Cho and K. H. Rhee, "Pathogenesis and prevention of stomach cancer", J. Korean Med. Sci., 11, pp. 373 - 385, 1996.

[3] K. Huh, T. H. Kwon, U. S. Shin, W. B. Kim, B. O. Ahn, T. Y. Oh and J. A. Kim, "Inhibitory effects of DA-9601 on ethanol-induced gastro-hemorrhagic lesions and gastric xanthine oxidase activity inrats", J. Ethnopharmacol., 88, pp. 269-273, 2003.

[4] E. B. Lee, O. J. Kim, S. S. Kang and C. C. Jeong, "Araloside A, an antiulcer constituent from the root bark of Aralia elata", Biol. Pharmac. Bull., 28, pp. 523-526, 2005.

[5] E. B. Lee, "The effect of Artemisia Herba on gastric lesion and ulcers in rats with isolation of eupatilin", Unesco Regional Seminar on the Chemistry, Pharmacology and clinical use of flavonoid compounds, pp. 13-20, 1995.

[6] S. E. Lee, J. H. Jeong, D. G. Kim and W. S. Choi, "Inhibitory effect on aflatoxin $\mathrm{B}_{1}-8$,9-epoxide formation and anti-complementary activity of methanol extract from Hericium erinaceus cultivated with Artemisia iwayomogi" Food Sci. Biotechnol., 12, pp. 183 -186, 2003.

[7] W. S. Choi, C. J. Kim, B. S. Park, S. E. Lee, G. R. Takeoka, D. G. Kim, X. L. Piao and J. H. Kim, "Inhibitory effect on proliferation of vascular smooth muscle cells and protective effect on $\mathrm{CCl}_{4}$-induced hepatic damage of HEAC extract" J. Ethnopharmacol., 100, pp. 176 - 179, 2005.

[8] G. Schmeda-Hirschmann, J. A. Rodr'iguez and L. Astudillo, "Gastroprotective activity of the diterpene solidagenone and its derivatives on experimentally induced gastric lesions in mice", J. Ethnopharmacol., 81, pp. $111-115,2002$.

[9] S. K. Kim, C. G. Son, C. H. Yun and S. H. Han, "Hericium erinaceum induces maturation of dendritic cells derived from human peripheral blood monocytes", Phytother. Res., 24, pp. $14-17,2010$. 
[10] M. H. Yim, J. W. Shin, J. Y. Son, S. M. Oh, S. H. Han, J. H. Cho, C. K. Cho, H. S. Yoo, Y. W. Lee and C. G. Son, "Soluble components of Herium erinaceum induced NK cell activation via production of interleukin-12 in mice splenocytes", Acta. pharmacol. Sinica., 28, pp. $901-9072007$.

[11] H. Xu, H. R. Wu, Z. Y. Shen and X. D. Chen, "Chemical analysis of Hericium erinaceum polysaccharides and effect of the polysaccharides on derma antioxidant enzymes, MMP-1 and TIMP-1 activities", Int. J. Biol. macromol., 2010.

[12] H. Kenmoku, T. Shimai, T. Toyomasu, N. Katon and T. Sassa, "Erinacine Q, a new erinacine from Hericium erinaceum, and its biosynthetic route to erinacine $\mathrm{C}$ in the basidomycete", Biosci. Biotechnol. Biochem., 66, pp. $571-575,2002$.

[13] E. W. Lee, K. Shizuki, S. Hosokawa, M. Suzuki, H. Suganuma, T. Inkauma, J. Li, M. Ohinishi-Kameyama, T. Nagata, S. Furukawa and H. Kawagishi, "Two novel diterpenoids, erinacines $\mathrm{H}$ and $\mathrm{I}$ from the mycelia of Hericium erinaceum", Biosci. Biotechnol. Biochem., 64, pp. $2402-2405,2000$.

[14] S. G. Lee, "The therapeutic effect of Artemisia capillaris extract on hepatic damage induced by carbon tetrachloride in rats", J. Vet., 22, pp. $206-213,2005$.

[15] B. Y. Ahn, H. S. Hwang, S. H. Baek, J. S. Kwak, D. S. Choi and J. H. Han, "Desmutagenic effect of water extract from Artemisia capillaries THUMB on the mutagenicity of benzo[a]pyrene. Korean J. Biotechnol. Bioeng., 15, pp. 331 -336, 2000.

[16] D. Hollander, W. J. Krause and J. Stachüra, "Is linoleic acid (diethyl essential fatty acid-EFA) cytoprotective for the gastric mucosa?", Gastroenterol., 88, pp. 610-614, 1985 .

[17] D. Hollander, A. Tarnawski and K. J. Ivey, "Arachidonic acid protection of rat mucosa against ethanol-induced injury", J. Lab. Clin. Med., 100, pp. 296-307, 1982.

[18] M. H. Pillinger, N. Marjanovic, S. Y. Kim, J. U. Scher, P. Izmirly, S. Tolani, V. Dinsell, Y. C. Lee, M. J. Blaser and S. B. Avramson, "Matrix metalloproteinase secretion by gastric epithelial cells is regulated by $\mathrm{E}$ prostaglandins and MAPKs", The ournal of biological chemistrry, Vol. 280, No. 11, pp. 9937-9979, 2005.

[19] J. S. Kim, K. Okamoto, S. Arima and B. K. Rubin, "Vasoactive intestinal peptide stiulates mucus secretion, but nitric oxide has no effect on mucus secretion in the ferret trachea.", J. Appl. Physiol, 101(2), 486-91, 2006.

[20] J. I. Isenberg, D. L. Hogan, M. A. Koss and J. A. Selling, "Human duodenal mucosal bicarbonate secretion. Evidence for basal secretion and stimulation of hydrochloric acid and a synthetic prostaglandin $\mathrm{E}_{1}$ ", Gastroenterol., 91, pp. 370-378, 1986.

[21] B. M. Peskar, K. Ehrlich and B. A. Peskar, "Interaction of cyclooxygenase-2 inhibitors and salicylate in gastric mucosal damage.", European Journal of Pharmacology 434, pp. 65-70, 2002.

[22] T. Matsuhisa and T. Rsukui, "Relation between reflux of bile acids into the stomach and gastric mucosal atrophy, intestinal metaplasia in biopsy specimens.", J. Clin. Biochem. Nutr, pp. 1-5, 2011.

[23] A. E. Ligha and H. B. Fawehinmi, "Protection by liquorice in alcohol induced gastric mucosa damage", Pak. J. Nutr., 8(10), pp. 1532-1536, 2009.

[24] A. M. nielsen, J. Hillingso, H. Frakiaer, K. Bukhave and J. R. madsen, "Gastric bicar-bonate secretion and release of prostaglandin E2 Are increased in duodenal ulcer patients but not on helicobacter pylori-positive healthy subjects.", Scand. J. Gastroenterol, Vol. 31, No. 1, pp. 38-43, 1996.

[25] S. M. Park, B. C. Yoo, H. R. Lee, H. Chung, Y. S. Lee, "Distribution of prostaglandin E2 in gastric and duodenal mucosa: possible role in the pathogenesis of peptic ulcer.", Korean J Intern. Med, 7(1), pp. 1-8, 1992.

[26] T. K. Razdan, B. Qadri, S. Harkar and E. S. Waight, "Chromenes and coumarins from Skimmia laureola", Phytochem., 26, pp. 2063 -2069, 1987.

Won-Sic Choi

[Regular member]

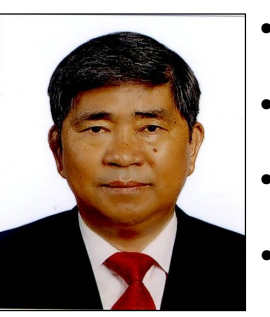

- Feb. 1974 : Korea Univ., Dept. of Chemistry (Bachelor)

- Feb. 1977 : Korea Univ., Dept. of Chemistry (Master)

- Feb. 2008 : Korea Univ., Dept. of Chemistry (Ph.D)

- Mar. $1982 \sim$ Feb. 1989 : Gangneung National Univ., Dept. of Chemistry, Professor

- Mar. $1989 \sim$ current : Soonchunhyang Univ., Dept. of Biotechnology., Professor

$<$ Research Interests $>$

Organic chemistry, Organic synthesis, Natural product chemistry 
Do-Yeon Jang

[Regular member]

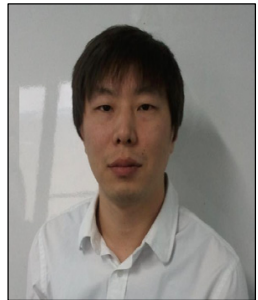

- Feb. 2002 : Soonchunhyang Univ., Dept. of Genetic engineering (Bachelor)

- Feb. 2004 : Soonchunhyang Univ., De[t. of Genetic engineering (Master)

- Feb. 2008 : Soonchunhyang Univ., Dept. of Genetic engineering (Ph.D)

- Feb. $2008 \sim$ current : Dongbang FTL, Synthesis Research Laboratory., Deputy manager

$<$ Research Interests $>$

Organic chemistry, Organic synthesis, Natural product chemistry

\section{Gyung-Rak Lee}

[associate member]

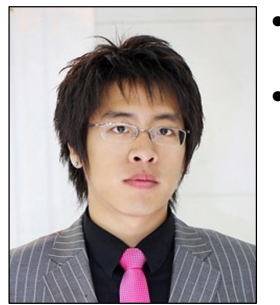

- Feb. 2011 : Soonchunhyang Univ., Dept. of Biotechnology (Bachelor)

- Mar. $2011 \sim$ current : Soonchunhyang Univ., Dept. of Biothenology., MS course

$<$ Research Interests $>$

Organic chemistry, Organic synthesis, Natural product chemistry

\section{Seung-Han Kim}

[associate member]

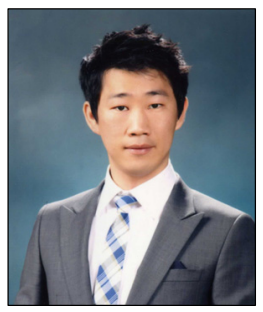

- Feb. 2012 : Soonchunhyang Univ., Dept. of Biotechnology (Bachelor)

- Mar. $2012 \sim$ current : Soonchunhyang Univ., Dept. of Biothenology., MS course

$<$ Research Interests $>$

Organic chemistry, Organic synthesis, Natural product chemistry 